\title{
The impact of GST implementation on the Malaysian stock market index volatility An empirical approach
}

\author{
Razali Haron \\ IIUM Institute of Islamic Banking and Finance, \\ International Islamic University Malaysia, Kuala Lumpur, Malaysia, and \\ Salami Mansurat Ayojimi \\ Kulliyyah of Economics and Management Sciences, \\ International Islamic University Malaysia, Kuala Lumpur, Malaysia
}

\begin{abstract}
Purpose - The purpose of this paper is to examine the impact of the Goods and Service Tax (GST) implementation on Malaysian stock market index.

Design/methodology/approach - This study used daily closing prices of the Malaysian stock index and futures markets for the period ranging from June 2009 to November 2016. Empirical estimation is based on the generalised autoregressive conditional heteroscedasticity $(1,1)$ model for pre- and post-announcement of the GST . Findings - Result shows that volatility of Malaysian stock market index increases in the post-announcement than in the pre-announcement of the GST which indicates that educative programs employed by the government before the GST announcement did not yield meaningful result. The volatility of the Malaysian stock market index is persistent during the GST announcement and highly persistent after the implementation. Noticeable increase in post-announcement is in support with the expectation of the market about GST policy in Malaysia.

Practical implications - The finding of this study is consistent with expectation of the market that GST policy will increase the price of the goods and services and might reduce standard of living. This is supported by a noticeable increase in the volatility of the Malaysian stock market index in the post-announcement of GST which is empirically shown during the announcement and after the implementation of GST. Although the GST announcement could be classified as a scheduled announcement, unwillingness to accept the policy prevails in the market as shown by the increase in the market volatility.

Originality/value - Past studies on Malaysian stock market index volatility focus on the impact of Asian and global financial crisis whereas this study examines the impact of the GST announcement and implementation on the volatility of the Malaysian stock market index.
\end{abstract}

Keywords GARCH, GST, KLCI-Futures, Market volatility

Paper type Research paper

\section{Introduction}

Goods and Service Tax (GST), a new tax approach in Malaysia, is a key component of the government's long-term fiscal reform initiatives. The GST was announced on 19 June 2014 and implemented on 1 April 2015. The GST imposes a 6 per cent tax on about 1,200 selected items. Several advantages and disadvantages of the GST have been aggressively discussed among all parties in the economy particularly the consumers, being a broad-based tax on consumptions; the GST can protect revenue from tax evasion by retailers, thus, ensures a

(C) Razali Haron and Salami Mansurat Ayojimi. Published in Journal of Asian Business and Economic Studies. Published by Emerald Publishing Limited. This article is published under the Creative Commons Attribution (CC BY 4.0) licence. Anyone may reproduce, distribute, translate and create derivative works of this article (for both commercial and non-commercial purposes), subject to full attribution to the original publication and authors. The full terms of this licence may be seen at http:// creativecommons.org/licences/by/4.0/legalcode

Malaysian stock market index volatility

Received 9 June 2018 Revised 14 September 2018 Accepted 14 November 2018 
JABES

26,1

18

stable and reliable source of revenue to the government and encourages saving as well as investments to the public (Narayanan, 2014). This is then translated into a more prosperous growth of the economy in particular and the country as a whole. Stable and strong revenue can increase employment creation and enhance the country's competitiveness.

Nevertheless, despite the advantages identified above, the announcement of GST has triggered immense worries, concerns and uncertainties to the public. The government has been delaying its implementations several times since its first introduction in the Malaysian Budget 2005 (Kraal and Kasipillai, 2016). According to Narayanan (2014), four major concerns have been thoroughly discussed since the announcement of the GST which are the concern on the possible effect on price level, the strong possibility of it being regressive that is, extracting bigger proportion of the earnings of lower incomes comparative to the higher incomes through the taxes, the possibility of the tax rate to increase overtime and the possible misuse of the revenue by irresponsible government due to corruption, opacity and lack of accountability in managing the collection (Narayanan, 2014). It is reported that the announcement of the GST has caused a shock in household spending pattern in Malaysia (Bank Negara Malaysia Economic Development Report, 2015). Anticipating price rise, households were seem to hurriedly purchase basic necessities and durable items like passenger cars, furniture and electrical appliances before the implementation of the GST. This is evidenced when a marked increase in car sales was observed, particularly in March 2015. Following this, private consumption expanded strongly by 8.8 per cent (IQ: 2015), significantly higher than its long-run average growth of 6.7 per cent (1990-2014). Most retailers, particularly supermarkets, experienced a substantial increase in sales during the last few weeks leading to the implementation of the GST.

GST is a new experience on a direct tax payment on some goods and services to the economy and to the households in Malaysia at large and can cause alarming shocks worries and uncertainties to the public and indirectly to the market. This study aims to investigate on how the market would react to the shocks and concerns triggered by the two phases of this tax reform, that is the announcement phase and the implementation phase. These kinds of shocks and uncertainties are evidenced to have significant impact on market volatility as documented in the past literature such as Bernile et al. (2016), Beber and Brandt (2006) and Vähämaa and Äijö (2011). The finding from this study and the examination on the effect of the GST pre- and post-announcement will provide crucial and beneficial empirical information with regard to the impact of the announcement and the implementation of a new tax reform on market volatility. Understanding the effect of macro-news on securities prices is essential to better understand market behaviour (Rühl and Stein, 2015). Effect of macro-news announcement on stock market is essential for market traders and policy makers for better decision making (Adjasi, 2009).

It is apparent that stock market index is volatile and it responds to future event even before the event actually takes place. This indicates a significant impact a piece of information has on the volatility of the market. Market starts reacting to new information immediately after an official announcement is made and in some cases market reacts differently after the event actually happens. Rangel (2011) stresses that to know how asset price as well as market volatility reacts to information released is essential for financial and economic decisions. Similarly, Michaelides et al. (2015) using cross-country data from 1988 to 2012 to find evidence of market negative reaction prior to sovereign rating downgrade announcement. Literature is compiling empirical evidences on impacts of macro-news announcement on financial markets. For example, Bernile et al. (2016) document how the release of macro-news can heavily impact capital markets while Chen and Gau (2010) reveal that announcement of macroeconomic indicators can alter market information structure. The body of knowledge also acknowledges evidences on how scheduled announcement affects market differently from unscheduled announcement. Studies like Beber and Brandt (2006) and Vähämaa and Äijö (2011) agree to 
the notion when they find that market volatility seems to drop reacting to scheduled announcement and otherwise for unscheduled announcement.

This study examines the effect of GST on the volatility of Malaysian stock market index. GST is chosen because it was relatively a new tax policy in the Malaysian context and an unwelcome tax policy among households. Thus, this study contributes to the existing literature in three ways. First, it extends the literature by establishing the relationship between GST implementation and KLCI market in the Malaysian context. Second, it provides better understanding on the impact of GST on the Malaysian stock market index. Finally, the study is different from previous studies that investigate relationship between macroeconomic variables and Malaysian stock market index volatility while controlling the effect of other macroeconomic variables such as producer price index (PPI), consumer price index (CPI) and unemployment rate (UNEMPR) on the findings.

To the best of our knowledge, our study on the impact of the GST on the Malaysian stock market index is novel and contributes significantly to the existing literature on market volatility. Previous studies focus on the impact of Asian financial crisis and/or global financial crises on Asian emerging countries. Realizing the significant of this new important event and gap it could cause in the literature of emerging market like Malaysia, this study is motivated to investigate the impact of the GST announcement and implementation on the Malaysian stock index and provides evidence by first examining the pre- and post-GST announcement on the Malaysian stock market index volatility and second, investigating whether there are changes in return to investors after the introduction of the GST. Then this study proceeds to examine the impact of the GST on the short-term and long-term volatility of the Malaysian stock market index. Bernile et al. (2016) emphasise the importance of measuring market expectation prior to the release of scheduled announcement and compare the difference between pre- and post-announcement.

First, we find in this study that volatility of Malaysian stock market index increases in post-announcement of GST than in pre-announcement. Worth noted that post-GST announcement volatility comprises of volatility of the market during announcement and after implementation of GST. Second, the result shows that lagged return of KLCI and KLCI-Futures (KLCI-F) are simultaneously significant to determine the changes in the stock return and the net benefit of investing in the Malaysian stock market index resulted in positive returns. The lagged returns of KLCI is negative while the lagged return of KLCI-F returns is positive with higher magnitude that might result in net profit which supports the futures index as risk management instrument. Third, the highest short-run volatility is observed in pre- announcement while the highest long-run persistent is recorded in post-announcement. Moreover, higher volatility persistent is found after the implementation of the GST as compared to the pre- and during announcement of the GST which could be translated into market reaction against GST policy in Malaysia.

The rest of the study is structured as follows: Section 2 outlines related literature and theoretical background on the impact of macro-news announcement on market volatility. Section 3 discusses the data, methodology employed and the analyses done in this study. Section 4 reports the empirical findings and the last section concludes the study.

\section{Related literature and theoretical background}

Tax policy is one of the theoretical constructs that link macro-news volatility with stock index return and are explained by arbitrage pricing theory (APT) and could be further understood by two dominant hypotheses namely the tax effect and the proxy effect hypotheses (Ross, 1976; Adjasi, 2009). APT relates return and risk as a linear function, while at the same time arguing that risk factors may be in multiples rather than single risk (Ross, 1976). It is a way of linking market return volatility with macroeconomic variables, whereby multiple factors can explain stock index return (Ross, 1976). APT takes into
Malaysian stock market index volatility 
JABES

26,1

account the influence of economic factors on the stock market index return (Buhl et al., 2011; Fan and Xu, 2011). Trzcinka (1986) concludes that APT remains valid as a risky asset pricing tool despite the argument on the number of factors needing to be constant before linearity of the relationship holds. According to Fama and French (1997), Blank (1989) and Bower et al. (1984), APT provides a clearer description of the expected stock return and is theoretically sound on the estimation of expected asset return. This is also supported in the study of Hodder and Jackwerth (2011), APT supports the view that macro-economy has a potential impact on asset return. In the context of this study, relationship between the macroeconomic news announcements and Malaysian stock market index volatility could also be explained by the tax effect hypothesis of Feldstein (1980) and proxy effect of Fama (1981). Both hypotheses argue that macroeconomic variable reduces stock market returns. Proxy effect hypothesis further explains that real activities are positively correlated with stock returns but negatively correlated with macroeconomic variables. As in the case of GST, it is directly imposed on the real activities such as selected goods and services. However, imposition of GST reduces purchasing power of the households by increasing price of goods and services.

Similarly, the impact of macro-news announcement on stock market volatility has caught the attention of researchers and policy makers over the years (Adjasi, 2009). Literature witnesses the development of this related study be segmented into issues, relationship between macro-news announcements and market volatility and the methodologies employed in examining the relationship. Macro-news announcement, as explained by some studies (Vrugt, 2009; Chen and Gau, 2010; Chulia et al., 2010; Jiang et al., 2012; Hitzemann et al., 2015; Bernile et al., 2016) is divided into scheduled and unscheduled announcement.

Bernile et al. (2016) suggest possible ways in which the Federal Open Market Committee (FOMC) announcement gets to the investors prior to official release of the macro-news. They point out that investors with superior ability might predict some upcoming FOMC announcement either through insiders mimic or media news and conclude that such investors could even trade during embargoes. They infer that having access to such private information has global implication such as the 2007-2008 financial crises. It is obvious that investors are not willing to take risk without commensurable return premium (Kongsilp and Mateus, 2017). Similarly, Chulia et al. (2010) examine the effects of FOMC announcement on S\&P 100 stock returns focusing on the individual stocks level. The result detects different reaction of the stocks towards the shocks. For example, the reaction of financial stocks is the strongest among all, followed by the IT stocks and the response of the utilities stocks is the least. A significant move in price was reported when surprise is related to expectation of the markets (Evans, 2011). These findings support buying behaviour of the Malaysian household prior to the implementation of GST. A record of increase in the sales of certain goods was reported prior to the announcement of GST while sluggish in the sales was later documented upon the implementation of GST. Expectation that price of the goods in which GST is imposed will increase at least by 6 per cent of the original price is one of the driving factors that triggered decision of making earlier purchase of some goods.

However, Hashimoto and Ito (2010) find that earlier disclosure of information content of $\mathrm{CPI}$ in Tokyo area prior to the implementation of $\mathrm{CPI}$ at the national level has been absorbed by the exchange rate. In contrary, the findings of Hashimoto and Ito (2010) on CPI disclosure support that GST policy posed worries on Malaysian market participants. Unlike CPI, GST was considered as additional burden that might deteriorate living standard of the households and was also considered as a policy that forces households to pay national debt deficit. This supports the finding of Rühl and Stein (2015) that stress on the expectation of the market matters in predicting reaction of the market towards macro-news announcement.

In addition, Hitzemann et al. (2015) report that prior to the announcement of emissions, the market was calm with no abnormal returns but on the event day there were abnormal returns 
reported followed by an increase in the market volatility. They argue that the announcement of emission has increased the volatility of the market. Likewise, Truong (2011) reveals that the Chinese equity markets acts as a driving force of abnormal returns in the post-earnings announcement. Rühl and Stein (2015) find that unexpected announcements have the strongest impact on the market volatility of the European blue chips and a short-run increase in spread prior to the European Central Bank announcement on interest rate decision. Evans (2011) reports a significant contribution of intraday jumps to price volatility and quantify the impact of the macro-news announcement to market shocks of being one-third of the shock in the market. Chen and Gau (2010) find scheduled announcement to have attracted more informed traders for short-term and speedy price discovery. This implies that several studies are arriving at a common conclusion that macro-news announcement has direct effect on the market volatility.

In line with earlier studies, Jiang et al. (2012) highlight differences in the impacts of scheduled news announcement and unscheduled news announcement of the implied volatility. Implied volatility dropped with scheduled news announcement while implied volatility increases with the unscheduled news announcement. They even point out that information uncertainty is resolved with scheduled announcements whereas, on the other hand, arises through unscheduled announcement. Contrastingly, Marshall et al. (2012) find a decline in the implied volatility on announcement day of the US macro-news but no significant change on the volatility of the market for pre- and post-announcement. Contrasting findings of Marshall et al. (2012) have not provided a debatable argument on the direct impact of macro-news announcement on the volatility of the market.

Rangel (2011) employs the generalised autoregressive conditional heteroscedasticity (GARCH) model to explain the effects of five macro-news announcement on S\&P 500 index which are centred on the CPI and PPI as a measure of inflation and the federal fund rate (FFR), the nonfarm payroll employment (NFP) and the UNEMPR. He finds a significant increase in the market volatility on the employment announcement day. Vrugt (2009) studies pre- and post-impact of macro-news announcement using the GARCH models. He finds different conditional variance for the pre- and post-announcement, and on the announcement day with low on the former but higher in the latter. Hanousek et al. (2009) use the GARCH model to examine the impact of local and foreign macro-news on new European Union (EU) stock markets. They find that macro-news is released before the commencement of the markets hence erasing the element of surprise to the market as the market has absorbed the news before the market actually begins. They also account for a negative impact of the US news on Prague market and Budapest market. Similarly, Budapest market is positively affected by the EU news while Warsaw market is unaffected by foreign news. There is a slight difference in the macro-news such as CPI, PPI, FFR, NFP and UNEMPR used in the study by Rangel (2011). That macro-news have been assumed to be welcomed and accepted as a standard approach unlike GST that Malaysian Government strives over years on its implement and keep postponing to prevent negative consequences on the political party in the future, still GST policy was not considered as favourable policy by Malaysian.

Hence, impact of macro-news announcement on volatility requires appropriate modelling techniques to capture differences in the market volatility in relation to the macro-news announcement. Accurate volatility forecast delivers reliable information about future volatility to the market participant and volatility is crucial for asset pricing (Kongsilp and Mateus, 2017). As reported in several studies, volatility varies with expected and unexpected macro-news announcement of similar magnitude (Mollah and Mobarek, 2009; Tsai and Chen, 2009; Robbani et al., 2013).

\section{Data and methodology}

Daily closing prices of KLCI and KLCI-F are obtained from DataStream database for the period ranging from 1 June 2009 to 15 November 2016. We also obtained CPI, PPI and UNEMPR data
Malaysian stock market index volatility 
JABES

26,1

from the Department of Statistic, Malaysia. The macroeconomic data are available in monthly basis. We convert the monthly data to daily data using cubic spline. Similarly, Buyuksahin and Robe (2014) used cubic spline to convert monthly data to daily data in their study on speculators, commodities and cross-market linkages. In addition, price series are grouped into four different categories to provide more in-depth report on the impact of the GST on Malaysian stock market index volatility. The first group of data which ranges from 1 June 2009 to 18 June 2014 captures the volatility of Malaysian stock market index in the pre-announcement of the GST. The second group of data which ranges from 19 June 2014 to 15 November 2016 captures the volatility of the market in the post-announcement of the GST. The second group of data is further divided into two subgroups in order to examine the differences in market volatility during the announcement and after the implementation of the GST. The data for the first subgroup range from 19 June 2014 to 31 March 2015 and the data for the second subgroup range from 1 April 2015 to 15 November 2016.

Since this study is examining the impact of GST on Malaysian stock market index volatility, the effects of CPI, PPI and UNEMPR are controlled to prevent biasness in the conclusion of this study. Several studies that have already established the effect of macroeconomic factors on the stock market index volatility have documented relationship in the stock index return and macroeconomic variables such as CPI, PPI and UNEMPR (Chen and Gau, 2010; Nguyen, 2011; Rangel, 2011; Nguyen and Ngo, 2014; López, 2015); therefore, controlling for such macroeconomic variables is required. Previous studies show that uncertainty related to $\mathrm{CPI}$ as macroeconomic variable may affect return volatility and financial markets are influenced by macroeconomic trend such as CPI (Cai et al., 2009; Liu and Zhang, 2015). UNEMPR is regarded as one of the economic factors that is associated with the increase in inflation (as measured by CPI). Nguyen (2011) reports significant effect of UNEMPR on the conditional mean of the study. Therefore, controlling for those macroeconomic factors is essential in examine the impact of GST on Malaysian KLCI return volatility.

Data are transformed using logarithm compounding returns as below:

$$
R_{t}^{s f}=100 \times \log \left(P_{t} / P_{(t-1)}\right),
$$

where $R_{t}^{s f}$ represents return of spot or return of futures, $P_{t}$ represents current price of spot index or futures index price while $P_{t-1}$ represents lagged price of the spot index or futures index price.

This study employs the Augmented Dickey-Fuller (ADF) and Phillips-Perron (PP) unit root tests for stationarity test. $\mathrm{ADF}$ and $\mathrm{PP}$ unit root tests capture both parametric and non-parametric tests in the respective order (Jain et al., 2013). Robustness of error distribution is required and unit root test provides necessary information about order of integration of the series (Hansen and Lunde, 2005; Cabrera and Schulz, 2016).

In this study, GARCH $(1,1)$ model is used to examine volatility of the Malaysian stock market index with respect to the announcement of the GST, while controlling for other macroeconomic variables such as PPI, CPI and UNEMPR. The GARCH models capture volatility properties such as volatility persistent and clustering. Previous studies show that characteristic nature of returns series could be better explained by using GARCH models and the GARCH $(1,1)$ outperforms other forms of GARCHs (Hansen and Lunde, 2005; Vrugt, 2009; Hanousek and Kocenda, 2011).

In reference to the study of Haugom et al. (2014), GARCH modelling techniques of examining market volatility make volatility of the market becomes an observable variable. Hence, appropriate volatility models are required to explore necessary volatility features in the study to prevent spurious conclusion of the market volatility. In this study, we also control other macroeconomic factors that might increase volatility of Malaysian stock market index to prevent 
estimation bias that might lead to spurious conclusion and provide robustness in the findings. The general mean equation of the GARCH model is expressed as follows:

$$
Y_{t}=\alpha+\beta^{\prime} X_{t}+\varepsilon_{t}, \quad \varepsilon_{t} \mid \Omega_{t} \sim N\left(0, h_{t}\right),
$$

where $X_{t}$ represents $k \times 1$ vector of independent variables, $\beta$ represents $k \times 1$ vectors of coefficient, $\varepsilon_{t}$ represents error term fulfilling the assumption of $\varepsilon_{t} \mid \Omega_{t} \sim N\left(0, h_{t}\right)$. $\Omega$ represents information set. A more specific mean equation is expressed below.

Mean equations for RKLCI and RKLCI-F volatility:

$$
\begin{aligned}
\Delta R_{t}^{s} & =\alpha_{0}+\beta_{1} R_{t-i}^{s}+\beta_{2} R_{t-i}^{f}+\Delta L P P I_{t}+\Delta L C P I_{t}+\Delta L U N E M P R_{t}+\varepsilon_{t}, \\
\varepsilon_{t} \mid \Omega_{t} & \sim \operatorname{iid} N\left(0, h_{t}\right) .
\end{aligned}
$$

Besides the specific mean equations, the second moment equation of the GARCH model is expressed as follows:

$$
h_{t}=\alpha_{0}+\sum_{i=1}^{p} \lambda_{i} h_{t-i}+\sum_{j=1}^{q} \gamma_{j} u_{j-i}^{2} .
$$

where $h_{t}$ represents conditional variance composed of its own and squared errors lagged values. $\sum_{i=1}^{p} \lambda_{i}$ represents the short-run persistence (ARCH term), $\sum_{j=1}^{q} \gamma_{j}$ represents GARCH term and long-run persistent is determined by the sum of ARCH term and GARCH term $\left(\sum_{i=1}^{p} \lambda_{i}+\sum_{j=1}^{q} \gamma_{j}\right) ; p$ and $q$ are non-negative integers. $\Delta P P I_{t}$ represents first difference of PPI at time $t, \Delta C P \bar{I}_{t}$ represents CPI at time $t$ and $\triangle U N E M P R_{t}$ represents UNEMPR at time $t$.

Optimality of GARCH model is determined based on information criteria such as the Akaike information criterion (AIC) and the Schwarz information criterion (SIC). Model with smaller value of AIC and SIC is selected as the optimal model (Fan and Xu, 2011). Gil-Alana and Tripathy (2014) suggest using information criteria to select optimal model followed by diagnostic test. Several studies select the best forecasted model based on the lowest value of RMSE (Anderson et al., 2009; Cartea and Karyampas, 2011; Prokopczuk and Simen, 2014). RMSE equation is expressed as follows as in the study of Wang et al. (2016):

$$
R M S E=\frac{1}{n} \sum_{i-1}^{n}\left(\sigma_{i}^{2}-\hat{\sigma}_{i}^{2}\right)^{2},
$$

where $\sigma_{i}^{2}$ represents the actual realized volatility of the model, $\hat{\sigma}_{i}^{2}$ represents estimated realised volatility and $n$ represents number observations for forecast.

The presence of heteroscedasticity in the residuals of the model is examined through the ARCH effect test and common model employed is Engle's Lagrange multiplier test (Basher and Sadorsky, 2016). It is also noted that ARCH effect test is a sufficient condition for estimating market volatility (Tse and Booth, 1996; Le Pen and Sévi, 2010). The details on the preliminary test are provided in Tables I and II.

\section{Results and analysis}

Table I provides the properties of $R_{t}^{s}$ and $R_{t}^{f}$ prices through statistics summary. On average, the mean of $R_{t}^{s}$ and $R_{t}^{f}$ are positive for all data, and post-announcement while the mean of subdivisions are negative and the mean of pre-announcement is a mixture of positive and negative. Standard deviation of $R_{t}^{s}$ and $R_{t}^{f}$ are positive and are less than 1 for all groups. However, the value of mean and the standard deviation shows that unconditional daily returns display flatter tails than normal distribution of assumed normality and homoscedasticity, hence, making it suitable to be modelled on GARCH techniques 
JABES

26,1

\begin{tabular}{|c|c|c|c|c|c|c|c|c|}
\hline & Mean & Minimum & Maximum & SD & Skewness & Kurtosis & Jarque-Bera & Observation \\
\hline \multicolumn{9}{|c|}{$\begin{array}{l}1 \text { June } 2009 \text { to } 16 \text { August } 2016 \\
\text { All data }\end{array}$} \\
\hline $\begin{array}{l}R_{t}^{s} \\
R_{t}^{f}\end{array}$ & $\begin{array}{l}0.0003 \\
0.0003\end{array}$ & $\begin{array}{l}-0.0274 \\
-0.0353\end{array}$ & $\begin{array}{l}0.0332 \\
0.0482\end{array}$ & $\begin{array}{l}0.0058 \\
0.0070\end{array}$ & $\begin{array}{l}-0.2392 \\
-0.1591\end{array}$ & $\begin{array}{l}5.3491 \\
6.4644\end{array}$ & $\begin{array}{l}\text { 465.9870* } \\
981.3561^{*}\end{array}$ & $\begin{array}{l}1,946 \\
1,946\end{array}$ \\
\hline
\end{tabular}

$24 \quad 1$ June 2009 to 18 June 2014

Pre-announce

$\begin{array}{rrrrrrrrr}R_{t}^{s} & 0.0004 & -0.0253 & 0.0322 & 0.0056 & -0.2421 & 5.7511 & 428.1839^{*} & 1,317 \\ R_{t}^{f} & -0.0004 & -0.0351 & 0.0482 & 0.0068 & -0.1035 & 6.9783 & 870.8498^{*} & 1,317\end{array}$

19 June 2014 to 16 August 2016

Post-announce

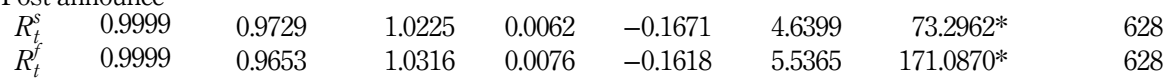

19 June 2014 to 31 March 2015

During announce

$\begin{array}{ccccccccc}R_{t}^{s} & -0.0004 & -0.0237 & 0.0162 & 0.0062 & -0.2294 & 3.9186 & 8.9189^{* *} & 203 \\ R_{t}^{f} & -0.0004 & -0.0289 & 0.0211 & 0.0077 & -0.0305 & 3.6579 & 3.6929 & 203\end{array}$

Table I.

Descriptive statistics of returns series of RKLCI $\left(R_{t}^{s}\right)$ and $\operatorname{RFKLI}\left(R_{t}^{f}\right)$

1 April 2015 to 16 August 2016

After implement

$\begin{array}{lllrrrrrr}R_{t}^{s} & -0.0004 & -0.0274 & 0.0222 & 0.0062 & -0.1997 & 5.0746 & 78.8526^{*} & 424 \\ R_{t}^{f} & -5.4135 & -5.4632 & -5.3261 & 0.0218 & 0.2561 & 3.5014 & 9.0775^{* *} & 424\end{array}$

Notes: $R_{t}^{s}$ and $R_{t}^{f}$ represent spot return (RKLCI) and futures return (RKLCI-F), respectively. Total data are disaggregated based on the date of event and the statistics summary is provided accordingly. ***Significant at the 1 and 5 per cent levels, respectively

(De Pinho et al., 2016). Moreover, return series are negatively skewed and leptokurtic (kurtosis $>3$ ) which reflected the non-normality distribution assumptions. Similarly, statistical significance of Jarque-Bera is an indication of non-normal distribution of error terms of returns which implies that return series are significantly larger than in a normal distribution (Choudhry and Hassan, 2015). In general, descriptive summary of the logarithm return series rejects the normal distribution of error term of the series.

Since the returns are confirmed non-normality of error distribution, generalised error distribution (GED) is employed. GED or Student's $t$ is a common error distribution technique mostly employed in the previous studies (Tripathy and Gil-Alana, 2015). Besides, Table II provides details on the stationarity of $R_{t}^{s}, R_{t}^{f}, \Delta P P I_{t}, \Delta C P I_{t}$ and $\triangle U N E M P R_{t}$.

Table II shows the intercept, trend and the intercept values for the $\mathrm{ADF}$ and $\mathrm{PP}$ unit root tests. The return series are stationary at level, which shows mean reversion property of the return as a satisfactory condition for using the return for modelling. The return series are integrated of order zero, $I \sim(0)$. However, PPI, CPI and UNEMPR are integrated of order one, $I \sim(1)$. Therefore, first difference of the macroeconomic variables is used for control variables. Understanding of time-series properties such as stationarity prior to main empirical analysis is essential to avoid spurious results (Haron and Salami, 2015).

Finally on the preliminary test, we examine the ARCH effect test. The ARCH effect test is to examine the homoscedastic of the variables and it is a common phenomenon in the studies relating to market volatility (Mensi et al., 2014; Basher and Sadorsky, 2016). The test for homoscedastic (ARCH effects test) prior to forecast volatility of market is well reported in previous studies (Haixia and Shiping, 2013; Gil-Alana and Tripathy, 2014). Reboredo et al. (2016) find $\mathrm{ARCH}$ effects in seven out of the eight markets being examined. ARCH effects test result provides sufficient condition to forecast the volatility of the Malaysian stock market index. 

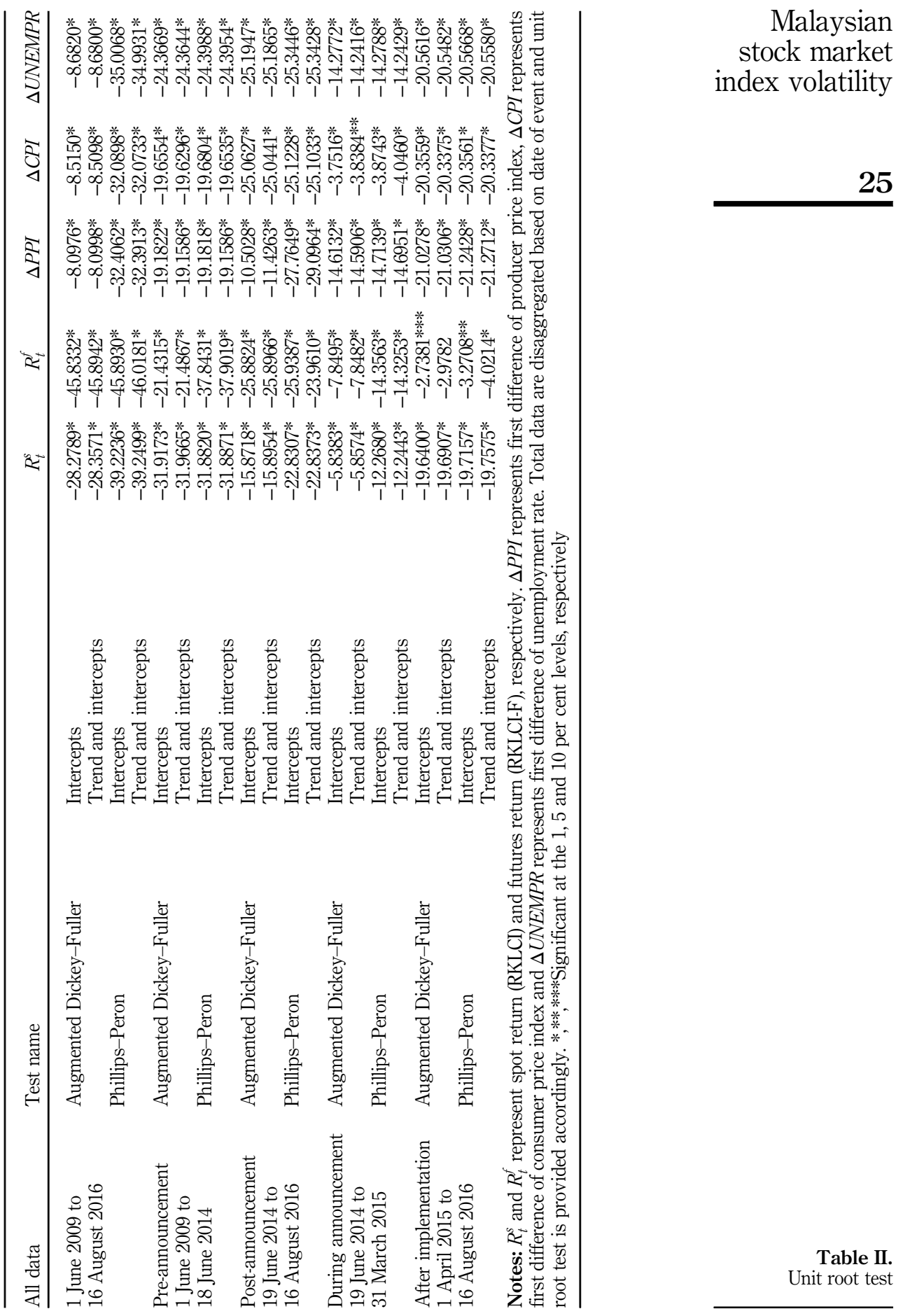

25

Table II. Unit root test 
JABES

26,1

26

The ARCH LM test is carried out and the test confirms the presence of ARCH effect in the return series therefore we proceed with GARCH model that examines the impact of GST on the volatility of the Malaysian stock market index and the results are provided in Tables III and IV.

In Table III, the pre- and post-impact of the GST is examined on the volatility of Malaysian stock market index using $\operatorname{GARCH}(1,1)$ model. In each situation, conditional mean and conditional variance results are presented. The non-negativity of the coefficient of $\operatorname{ARCH}(\gamma)$ and GARCH $(\lambda)$ terms are not violated. Short-term shock as indicated by the coefficient of ARCH term is generally small in this study. Returns shocks captured in the ARCH term is relatively small (Wu and Xiao, 2002). The ARCH and GRACH terms satisfy the non-negativity of Bollerslev which indicates gradual fading away of generated volatility in underlying prices due to temporary exogenous shocks (Haron and Salami, 2015).

\section{Pre-GST announcement}

The conditional mean shows that on average, mean of Malaysian stock market index (KLCI) is determined by lagged of its own return, current return of futures price and lagged return of the futures return keeping PPI, CPI and UNEMPR constant. This implies that the performance of the market return and its futures returns is significantly necessary for the current return in the Malaysian stock market index. The average lagged return of the KLCI is negative and statistically significant. However, average lagged return of the KLCI-F and average current KLCI-F return are positive and statistically significant in the pre-GST announcement. This findings are consistent with several other studies (Asgharian and Nossman, 2011;

\begin{tabular}{llcc}
\hline & & Pre-GST announcement & Post-GST announcement \\
Equations & & GARCH & GARCH \\
\hline Mean equation & $\alpha$ & $0.0000(0.4441)$ & $0.1882^{*}(12.6390)$ \\
& $R_{t-1}^{s}$ & $-0.3177^{*}(-6.5204)$ & $-0.2270^{*}(-8.9156)$ \\
& $R_{t}^{f}$ & $0.7334^{*}(39.8910)$ & $0.7250^{*}(183.7495)$ \\
& $R_{t-1}^{f}$ & $0.3783^{*}(9.0635)$ & $0.3137^{*}(19.2247)$ \\
& $\Delta L P P I$ & $0.0106(0.4039)$ & $-0.0059(-0.2501)$ \\
& $\Delta L C P I$ & $-0.0018(-0.0298)$ & $0.0449(1.2002)$ \\
Variance equation & $\Delta L U N E M P R$ & $-0.0020(-0.2484)$ & $-0.0009(-0.0697)$ \\
& $\alpha$ & $0.0000(1.3920)$ & $0.0000(1.5147)$ \\
& $\gamma$ & $0.1035^{* * *}(1.7717)$ & $0.0677^{* *}(2.0699)$ \\
& $\lambda$ & $0.7272^{*}(4.5446)$ & $0.8894^{*}(18.5046)$ \\
& GED & $1.7427^{*}$ & $1.2709^{*}$ \\
& AIC & -9.4670 & -9.1328 \\
& SIC & -9.3432 & -9.0549 \\
& Adj. $\bar{R}^{2}$ & 0.8082 & 0.8127 \\
& RMSE & 0.0023 & 0.0028 \\
& MAE & 0.0018 & 0.0021 \\
& D-W & 2.1764 & 2.3097 \\
& ARCH 1 & 0.4279 & 0.7824 \\
& ARCH 2 & 0.6766 & 0.6797 \\
$Q^{2}$ Stat(8) & 0.506 & 0.988
\end{tabular}

Notes: $t$-Statistics values are provided in parentheses. Optimality of the GARCH models is provided by AIC and SIC criteria. GED parameter indicates error distribution. Model with lowest value of RMSE and MAE is considered as the best model. Some statistical reports such as adjusted $\bar{R}^{2}$, AIC and SIC, RMSE and MAE are taken note of and diagnostics tests such as ARCH test and $Q^{2}$-statistic are provided after variance equation

Table III.

Empirical evidence of the GST announcement result. $R_{t-1}^{s}$ and $R_{t-1}^{f}$ represent lagged spot return (RKLCI) and lagged futures return (RKLCI-F), respectively. $\Delta L P P I_{t}, \Delta L C P I_{t}$ and $\triangle L U N E M P R_{t}$ are first difference logarithm value of control macroeconomic variable, namely producer price index, consumer price index and unemployment rate, respectively. Total data are disaggregated based on date of event. *******Significant at the 1,5 and 10 per cent levels, respectively 


\begin{tabular}{|c|c|c|c|}
\hline Equations & & $\begin{array}{c}\text { During announcement } \\
\text { GARCH }\end{array}$ & $\begin{array}{l}\text { After implementation } \\
\text { GARCH }\end{array}$ \\
\hline \multirow[t]{7}{*}{ Mean equation } & $\alpha$ & $-0.0002(-0.4068)$ & $0.1656^{* * *}(2.5394)$ \\
\hline & $R_{t-1}^{s}$ & $-0.1846(-1.2648)$ & 0.1577 ** (2.4618) \\
\hline & $R_{t}^{f_{-}^{-1}}$ & - & $0.1138 * *(2.9266)$ \\
\hline & $R_{t-1}^{f}$ & $0.2898 * *(2.5654)$ & $-0.0833^{* *}(-1.9680)$ \\
\hline & $\Delta L P P I$ & $-0.0401(-0.2757)$ & $0.1138(0.0207)$ \\
\hline & $\triangle L C P I$ & $-0.0111(-0.2768)$ & $0.0955(0.5121)$ \\
\hline & $\triangle L U N E M P R$ & $0.2094(0.9371)$ & $0.0062(0.1480)$ \\
\hline \multirow[t]{10}{*}{ Variance equation } & $\alpha$ & $0.0000(0.9528)$ & $0.0000 * * * *(1.8652)$ \\
\hline & $\gamma$ & 0.1035 (1.2485) & $0.0820^{* *}(2.4013)$ \\
\hline & $\lambda$ & $0.8088^{*}(5.1627)$ & $0.8757 *(20.3214)$ \\
\hline & GED & $1.7716^{*}$ & $1.5878^{*}$ \\
\hline & AIC & -7.3621 & -75540 \\
\hline & SIC & -7.1983 & -7.4488 \\
\hline & Adj. $\bar{R}^{2}$ & 0.0313 & 0.0090 \\
\hline & RMSE & 0.0062 & 0.0062 \\
\hline & MAE & 0.0048 & 0.0045 \\
\hline & W-D & 2.0563 & 1.9984 \\
\hline \multirow[t]{3}{*}{ Diagnostic test } & ARCH 1 & 0.3483 & 0.7560 \\
\hline & ARCH 2 & 0.4090 & 0.6699 \\
\hline & $Q^{2}$-Stat & 0.168 & 0.576 \\
\hline
\end{tabular}

Malaysian stock market index volatility

Notes: $t$-Statistics values are provided in parentheses. Optimality of the GARCH models is provided by AIC and SIC criteria. GED parameter indicates error distribution. Model with lowest value of RMSE and MAE is considered as the best model. Some statistical reports such as adjusted $\bar{R}^{2}$, AIC and SC, RMSE and MAE are taken note of and diagnostics tests such as ARCH test and $Q^{2}$ statistics are provided after variance equation result. $R_{t}^{s}, R_{t}^{f}, \triangle P P I, \triangle C P I, \triangle U N E M P R$ represent lagged spot return (RKLCI) and lagged futures return (RKLCI-F), respectively. $\triangle L P P I_{t}, \triangle L C P I_{t}$ and $\triangle L U N E M P R_{t}$ are first difference logarithm value of control macroeconomic variable, namely producer price index, consumer price index and unemployment rate, respectively. Total data are disaggregated based on date of event. Total data are disaggregated based on date of event. A relatively small $R^{2}$ does not prevent investors from making significant economic gain (Narayan et al., 2013). *******Significant at the 1, 5 and 10 per cent levels, respectively

Table IV. During the GST announcement and after the GST implementation

Mensi et al., 2013; Camilleri and Green, 2014). It is further explained in some studies that the magnitude of lagged return explains the volatility (Daouk and Ng, 2011; López, 2015). However, some studies such as Chen and Gau (2010) and Bouri (2015) find a contradictory result. Bouri (2015) finds positive effects of lagged oil return on the Lebanese stock and also Manera et al. (2014) find positive lagged of the S\&P 500 index. Chen and Gau (2010) also find a negative relationship between spot and futures prices. In the case of the study by Camilleri and Green (2014), only the first lagged return is statistically significant while other lags are not. Furthermore, a mixed result of negative and positive significant lagged returns are found in the study by Asgharian and Nossman (2011) and Mensi et al. (2013).

Negative coefficient of lagged return of the KLCI is excessively covered by investing in the KLCI-F. This implies that despite the average returns of investing in the Malaysian stock market index generates negative returns, investors are better off by taking opposite position in the futures market as the returns are positive with larger magnitude as compared to the underline market. This indicates that taking an opposite position of Malaysian stock market index in its futures market enables investors to reap the profit at least equivalent to risk-free rate irrespective of the price movement.

In the conditional variance, the $\mathrm{ARCH}$ and $\mathrm{GARCH}$ terms provide information on the extent of market volatility in the short run and long run, respectively. The $\mathrm{ARCH}$ term provides information on the effect of past innovations on the current volatility while the GARCH term explains past volatility on current volatility (Bouri, 2015). Persistent and clustering features of 
JABES

26,1

the volatility are also captured. Volatility in the short run is smaller in magnitude relative to the long run for all GARCH models. Investors might not put more concern on the short-run volatility as the effect may be wiped-off in the short run. More emphasis is put on the long-run volatility of the market which might have future consequence on the entire return of the market. Basher and Sadorsky (2016) report that the short-term persistent is lower as compared to the long-term persistent. Short-run volatility as denoted by ARCH (1) is relatively small as compared to longrun volatility (GARCH (1)) and ARCH term provides information about the rate at which volatility changes (Bouri, 2015; Chang et al., 2011). The GARCH model mainly captures the persistence of volatility and volatility clustering (Charles and Darne, 2014). The persistent volatility coefficient in the pre-announcement of GST in Malaysian stock market index is 0.8307 . This indicates that market volatility is mere persistent but clustering as the sum coefficient of the ARCH and GARCH terms is statistical significant (Hanousek et al., 2009). According to Bouri (2015), highly persistent market volatility is assumed when the sum of ARCH and GARCH coefficient is closer to unity (1).

This indicates that prior to the introduction of the GST Malaysian stock market index volatility is considerably moderate. The investors are not facing higher risk. Other economic factors such as CPI, PPI and UNEMPR are considerably stable and do not exercise negative effect on the market that may trigger increase in the volatility of the market. The result of the pre-GST announcement supports APT as number of the macroeconomic variables account for price determination in the Malaysian stock market index.

\section{Post-GST announcement}

The report on the conditional mean of the GARCH model in the post-GST announcement is similar but differs in magnitude. There is a need to point out some noticeable differences in the first moment return of the post-GST announcement. Negative lagged return of the KLCI is absolutely lower and the lag return of KLCI-F reduced after the GST has been announced and implemented. This indicates futures market consistently maintaining its role as risk mitigation technique as the magnitude of price risk exposures and risk reduction is proportional.

In the conditional variance of the model, the coefficient of the ARCH term is statistically significant in the post-GST announcement but is relatively reduced as compared with the pre-GST announcement. This implies that short-run volatility is further reduced while long-run volatility increased after the announcement of the GST. Further reduction in the short-run volatility is supported by APT as arbitrage opportunity may be short-lived. Such an increase in long-run volatility after the GST announcement has made overall volatility (0.9571) of Malaysian stock market index after the GST announcement to be more persistent compared with the pre-GST announcement (0.8307). The finding is consistent with the findings by Rangel (2011) and Vrugt (2009) where they find noticeable volatility changes upon macro-news announcement. High volatility of underline market increases the motivation of investors to hedge their position in the futures market (Chen and Gau, 2010). On the other hand, the finding is inconsistent with the tax effect hypothesis that proposed that macro-news announcement lowers the volatility of the market. Such an increase in the volatility of underlying market may increase negotiation for higher return.

For more in-depth study on the volatility of Malaysian stock market index in the post-GST announcement, we proceed to separate the impact of GST on the volatility of the Malaysian stock market index into during the GST announcement and after GST implementation which is presented in Table IV.

Table IV provides the volatility details during the announcement and after the implementation of the GST. The table shows both conditional mean and conditional variance results of the $\operatorname{GARCH}(1,1)$. 
The average lagged return of the Malaysian stock market index remains negative but insignificant while the average lagged return of the KLCI-F remains positive and significant for the model. This indicates that the announcement of GST has significant effect on Malaysian stock market index lag return. In contrast, average lagged return of its futures return (KLCI-F) is unaffected as its role is to mitigate price risk exposures.

In the conditional variance of the model, the short-run volatility remains as in the pre-GST announcement while the long-run volatility is higher than as in the pre-GST announcement but lower than as in the post-GST announcement. The overall volatility during the GST announcement is highly persistent (0.9123) than in the pre-GST announcement but lesser persistent as in the post-GST announcement. This implies that the announcement of GST has significant impact on the volatility of Malaysian stock market index volatility which increases the overall volatility of the Malaysian stock market index. The finding is consistent with the study of Vrugt (2009) that finds volatility change upon the announcement of macro-news. Similarly, unwelcome announcement is associated with jump in the returns (Rangel, 2011).

Impact of the GST on the Malaysian stock market index volatility in the short run is statistically insignificant. This could be a reflection that announcement of GST has become publicly available information during the period and less consumption is recorded as many households have already increased their purchases prior to the imposition of the GST. In contrary to that, long-run volatility increases and the effect of the GST on the price of the goods and services becomes noticeable as its impact reduces purchasing power.

\section{After GST implementation}

In the conditional mean after GST implementation, average lagged returns of Malaysian stock market index and own futures return are positively significant, while lagged return of its futures is negatively significant. This implies that both the KLCI and KLCI-F returns are significantly important in determining the volatility of Malaysian stock market index but in different magnitude and direction.

In the conditional variance of the model, short-run volatility is lower relative to during the announcement while the long-run volatility is more persistent than during the announcement of the GST. The volatility persistent after GST implementation (0.9577) is higher compared with the volatility in the pre-GST announcement $(0.8307)$ and during the GST announcement (0.9123) and slightly higher compared with the volatility of the postGST announcement (0.9571). This shows that Malaysian stock market index volatility is highly persistent and clustering after the implementation of GST. This implies that the worries of the household that implementation of the GST might increase the volatility of the market is empirically confirmed. Although release of scheduled news clarifies information uncertainty (Jiang et al., 2012), this is not translated into volatility reduction in Malaysian stock market index. Rather, it increases volatility even during the transition process and further increases volatility of the market after the GST implementation. This finding supports the finding by Rühl and Stein (2015) that the direction of macro-news announcement is governed by the expectation of the market.

In general, findings of this study are supported by APT that risk and return are explained by more than one macroeconomic factors and arbitrage opportunity short-lived. Having control for CPI, PPI and UNEMPR, volatility of the Malaysian stock market index increases in the post-GST announcement than in the pre-GST announcement. However, the findings did not support the tax effect and proxy effect hypothesis as volatility of Malaysian stock market index increases instead of reduces as proposed by both hypotheses. Contradictory of this finding with the hypotheses may be supported by the expectation of the market and the unwilling attitude of the households to support the policy. 
JABES

26,1

Diagnostic tests for each model is not violated, the ARCH test provided in each column is statistically insignificant as well as the $Q^{2}$ statistics at eight lags. Hence, the findings are robust and not misleading.

\section{Conclusion}

This paper has shown the effect of GST on the Malaysian stock index return volatility while controlling for other macroeconomic factors such as PPI, CPI and UNEMPR that might equally trigger volatility on the market. This study employed GARCH $(1,1)$ model and results of diagnostic test show that results are robust as the findings are free from serial correlation, heteroscedasticity and multicollinearity. It seems that prior to the GST announcement, Malaysian stock market index volatility is merely persistent as compared with during the GST announcement and GST implementation. Increase in volatility of Malaysian stock market index during and after the GST announcement implies that GST awareness programs sponsored by the government did not accomplish a successful result. Market participants are not in support of the imposition of GST in Malaysia as empirically shown in this study by comparing the volatility level of the Malaysian stock market index in the pre- and post-GST announcement. It is also well documented in the body of knowledge that macroeconomic news announcement increases market volatility. The GST announcement could be categorised as scheduled announcement through several educative programs employed by the government, still the market volatility increases. This finding supports the finding by Bernile et al. (2016) and Chen and Gau (2010) that macroeconomic news announcement has significant impact on market volatility. However, the finding is contrary with the findings that scheduled macroeconomic news reduced market volatility as found by Beber and Brandt (2006) and Vähämaa and Äijö (2011). This finding further shows that the readiness of the market also matters on the macroeconomic news announcement as being scheduled news is not only a sufficient condition for the market volatility to be reduced. This finding supports the findings of Rühl and Stein (2015) that expectation matters on the direction of macro-news announcement.

In conclusion, the volatility of the Malaysian stock market index prior to the GST announcement is lower compared with the volatility of the market during the GST announcement and GST implementation. This finding further agrees with the expectation of the market participants and previous studies on the impact of macro-news on stock market index. We found that the imposition of GST increases price of the goods and services and reducing purchasing power of households. Such increase in the volatility of Malaysian stock market index is consistent with the expectation of the market.

\section{References}

Adjasi, C.K.D. (2009), "Macroeconomic uncertainty and conditional stock-price volatility in frontier African markets evidence from Ghana”, The Journal of Risk Finance, Vol. 10 No. 4, pp. 333-349.

Anderson, E.W., Ghysels, E. and Juergens, J.L. (2009), “The impact of risk and uncertainty on expected returns", Journal of Financial Economics, Vol. 94 No. 2, pp. 233-263.

Asgharian, H. and Nossman, M. (2011), "Risk contagion among international stock markets", Journal of International Money and Finance, Vol. 30 No. 1, pp. 22-38.

Bank Negara Malaysia Economic Development Report (2015), available at: www.bnm.gov.my/files/ publication/ar/en/2015/ar2015_book.pdf (accessed 12 May 2018).

Basher, S.A. and Sadorsky, P. (2016), "Hedging emerging market stock prices with oil, gold, VIX, and bonds: a comparison between DCC, ADCC and GO-GARCH”, Energy Economics, Vol. 54 No. 1, pp. 235-247.

Beber, A. and Brandt, M.W. (2006), "The effect of macroeconomic news on beliefs and preferences: evidence from the options market”, Journal of Monetary Economics, Vol. 53 No. 8, pp. 1997-2039.

Bernile, G., Hu, J. and Tang, Y. (2016), "Can information be locked up? Informed trading ahead of macro-news announcements”, Working Paper, Vol. 121 No. 1, pp. 496-520. 
Blank, S.C. (1989), "Research on futures markets: issues, approaches, and empirical findings", Western Journal of Agricultural Economics, Vol. 14 No. 1, pp. 126-139.

Bouri, E. (2015), "Return and volatility linkages between oil prices and the Lebanese stock market in crisis periods”, Energy, Vol. 89 No. 1, pp. 365-371.

Bower, D.H., Bower, R.S. and Logue, D.E. (1984), “American finance association arbitrage pricing theory and utility stock returns", The Journal of Finance, Vol. 39 No. 4, pp. 1041-1054.

Buhl, H.U., Straub, S. and Wiesent, J. (2011), "The impact of commodity price risk management on the profits of a company", Resources Policy, Vol. 36 No. 4, pp. 346-353.

Buyuksahin, B. and Robe, M.A. (2014), "Speculators, commodities and cross-market linkages", Journal of International Money and Finance, Vol. 42 No. 1, pp. 38-70.

Cabrera, B.L. and Schulz, F. (2016), "Volatility linkages between energy and agricultural commodity prices”, Energy Economics, Vol. 54 No. 1, pp. 190-203.

Cai, Y., Chou, R.Y. and Li, D. (2009), "Explaining international stock correlations with CPI fluctuations and market volatility", Journal of Banking and Finance, Vol. 33 No. 11, pp. 2026-2035.

Camilleri, J.S. and Green, J.C. (2014), "Stock market predictability", Studies in Economics and Finance, Vol. 31 No. 4, pp. 354-370.

Cartea, Á. and Karyampas, D. (2011), "Volatility and covariation of financial assets: a high-frequency analysis", Journal of Banking and Finance, Vol. 35 No. 12, pp. 3319-3334.

Chang, C.L., McAleer, M. and Tansuchat, R. (2011), "Crude oil hedging strategies using dynamic multivariate GARCH”, Energy Economics, Vol. 33 No. 5, pp. 912-923.

Charles, A. and Darne, O. (2014), "Large shocks in the volatility of the Dow Jones industrial average index: 1928-2013", Journal of Banking and Finance, Vol. 43 No. 1, pp. 188-199.

Chen, Y.L. and Gau, Y.F. (2010), "News announcements and price discovery in foreign exchange spot and futures markets", Journal of Banking and Finance, Vol. 34 No. 7, pp. 1628-1636.

Choudhry, T. and Hassan, S.S. (2015), "Exchange rate volatility and UK imports from developing countries: the effect of the global financial crisis", Journal of International Financial Markets, Institutions and Money, Vol. 39 No. 1, pp. 89-101.

Chulia, H., Martens, M. and van Dijk, D. (2010), "Asymmetric effects of federal funds target rate changes on S\&P 100 stock returns, volatilities and correlations", Journal of Banking and Finance, Vol. 34 No. 4, pp. 834-839.

Daouk, H. and Ng, D. (2011), "Is unlevered firm volatility asymmetric?", Journal of Empirical Finance, Vol. 18 No. 4, pp. 634-651.

De Pinho, F.M., Franco, G.C. and Silva, R.S. (2016), "Modeling volatility using state space models with heavy tailed distributions", Mathematics and Computers in Simulation, Vol. 119 No. 1, pp. 108-127.

Evans, K.P. (2011), "Intraday jumps and US macroeconomic news announcements", Journal of Banking and Finance, Vol. 35 No. 10, pp. 2511-2527.

Fama, E.F. (1981), "Stock returns, real activity, inflation and money", American Economic Review, Vol. 71 No. 1, pp. 545-565.

Fama, E.F. and French, K.R. (1997), "Industry costs of equity”, Journal of Financial Economics, Vol. 43 No. 2, pp. 153-193.

Fan, Y. and Xu, J.H. (2011), "What has driven oil prices since 2000? A structural change perspective", Energy Economics, Vol. 33 No. 6, pp. 1082-1094.

Feldstein, M. (1980), "Inflation and the stock market", American Economic Review, Vol. 70 No. 5, pp. 839-847.

Gil-Alana, L.A. and Tripathy, T. (2014), "Modelling volatility persistence and asymmetry: a study on selected Indian non-ferrous metals markets", Resources Policy, Vol. 41 No. 1, pp. 31-39.

Haixia, W. and Shiping, L. (2013), "Volatility spillovers in China's crude oil, corn and fuel ethanol markets", Energy Policy, Vol. 62 No. 1, pp. 878-886. 
JABES

26,1

Hansen, P.R. and Lunde, A. (2005), "A forecast comparison of volatility models: does anything beat a GARCH(1,1)?”, Journal of Applied Econometrics, Vol. 20 No. 7, pp. 873-889.

Haron, R. and Salami, M.A. (2015), “'Malaysian crude palm oil market volatility': a GARCH approach”, International Journal of Economics and Management, Vol. 9 No. 1, pp. 103-120.

Hashimoto, Y. and Ito, T. (2010), "Effects of Japanese macroeconomic statistic announcements on the dollar/yen exchange rate: high-resolution picture", Journal of The Japanese and International Economies, Vol. 24 No. 3, pp. 334-354.

Haugom, E., Langeland, H., Molnár, P. and Westgaard, S. (2014), "Forecasting volatility of the US oil market”, Journal of Banking and Finance, Vol. 47 No. 1, pp. 1-14.

Hitzemann, S., Uhrig-Homburg, M. and Ehrhart, K.M. (2015), "Emission permits and the announcement of realized emissions: price impact, trading volume, and volatilities", Energy Economics, Vol. 51 No. 1, pp. 560-569.

Hodder, J.E. and Jackwerth, J.C. (2011), "Managerial responses to incentives: control of firm risk, derivative pricing implications, and outside wealth management", Journal of Banking and Finance, Vol. 35 No. 6, pp. 1507-1518.

Jain, P., Vyas, V. and Roy, A. (2013), "A study on weak form of market efficiency during the period of global financial crisis in the form of random walk on Indian capital market", Journal of Advances in Management Research, Vol. 10 No. 1, pp. 122-138.

Jiang, G.J., Konstantinidi, E. and Skiadopoulos, G. (2012), "Volatility spillovers and the effect of news announcements", Journal of Banking and Finance, Vol. 36 No. 8, pp. 2260-2273.

Kongsilp, W. and Mateus, C. (2017), "Volatility risk and stock return predictability on global financial crises”, China Finance Review International, Vol. 7 No. 1, pp. 33-66.

Kraal, D. and Kasipillai, J (2016), "Finally, a goods and services tax for Malaysia: a comparison to Australia's GST experience”, Australian Tax Forum, Vol. 31 No. 1, pp. 257-287.

Le Pen, Y. and Sévi, B. (2010), "Volatility transmission and volatility impulse response functions in European electricity forward markets", Energy Economics, Vol. 32 No. 4, pp. 758-770.

Liu, L. and Zhang, T. (2015), "Economic policy uncertainty and stock market volatility", Finance Research Letters, Vol. 15 No. 1, pp. 99-105.

López, R. (2015), "Do stylized facts of equity-based volatility indices apply to fixed-income volatility indices? Evidence from the US treasury market", International Review of Financial Analysis, Vol. 42 No. 1, pp. 292-303.

Manera, M., Nicolini, M. and Vignati, I. (2014), "Modelling futures price volatility in energy markets: is there a role for financial speculation?”, Energy Economics, Vol. 53 No. 1, pp. 220-229.

Marshall, A., Musayev, T., Pinto, H. and Tang, L. (2012), "Impact of news announcements on the foreign exchange implied volatility", Journal of International Financial Markets, Institutions and Money, Vol. 22 No. 4, pp. 719-737.

Mensi, W., Hammoudeh, S. and Yoon, S.M. (2014), "How do OPEC news and structural breaks impact returns and volatility in crude oil markets? Further evidence from a long memory process", Energy Economics, Vol. 42 No. 1, pp. 343-354.

Mensi, W., Beljid, M., Boubaker, A. and Managi, S. (2013), "Stock market volatility spillovers and portfolio hedging: BRICS and the financial crisis”, Economic Modelling, Vol. 32 No. 1, pp. 15-22.

Michaelides, A., Milidonis, A., Nishiotis, G.P. and Papakyriakou, P. (2015), "The adverse effects of systematic leakage ahead of official sovereign debt rating announcements", Journal of Financial Economics, Vol. 116 No. 3, pp. 526-547. 
Mollah, S. and Mobarek, A. (2009), "Market volatility across countries - evidence from international markets", Studies in Economics and Finance, Vol. 26 No. 4, pp. 257-274.

Narayan, P.K., Narayan, S. and Mishra, S. (2013), "Has the structural break slowed down growth rates of stock markets?”, Economic Modelling, Vol. 30 No. 1, pp. 595-601.

Narayanan, S. (2014), "The impact of the Goods and Services Tax (GST) in Malaysia: lessons from experiences elsewhere (a note)", The Singapore Economic Review, Vol. 59 No. 2, pp. 1-15.

Nguyen, T. (2011), "US macroeconomic news spillover effects on Vietnamese stock market", The Journal of Risk Finance, Vol. 12 No. 5, pp. 389-399.

Nguyen, T. and Ngo, C. (2014), "Impacts of the US macroeconomic news on Asian stock markets", Journal of Risk Finance, Vol. 15 No. 2, pp. 149-179.

Prokopczuk, M. and Simen, C.W. (2014), "The importance of the volatility risk premium for volatility forecasting", Journal of Banking and Finance, Vol. 40 No. 1, pp. 303-320.

Rangel, J.G. (2011), "Macroeconomic news, announcements, and stock market jump intensity dynamics", Journal of Banking and Finance, Vol. 35 No. 5, pp. 1263-1276.

Reboredo, J.C., Rivera-Castro, M.A. and Ugolini, A. (2016), "Downside and upside risk spillovers between exchange rates and stock prices", Journal of Banking and Finance, Vol. 62 No. 1, pp. 76-96.

Robbani, M.G., Bhuyan, R. and Sbeiti, W.M. (2013), "On the dynamics of volatility transmission: an empirical investigation on G-8 countries", Investment Management and Financial Innovations, Vol. 10 No. 1, pp. 166-173.

Ross, A.S. (1976), "The arbitrage theory of capital asset pricing”, Journal of Economic Theory, Vol. 13 No. 3, pp. 341-360.

Rühl, T.R. and Stein, M. (2015), "The impact of ECB macro-announcements on bid - ask spreads of European blue chips", Journal of Empirical Finance, Vol. 31 No. 1, pp. 54-71.

Tripathy, T. and Gil-Alana, L.A. (2015), "Modelling time-varying volatility in the Indian stock returns: some empirical evidence", Review of Development Finance, University of Cairo, Vol. 5 No. 2, pp. 91-97.

Truong, C. (2011), "Post-earnings announcement abnormal return in the Chinese equity market", Journal of International Financial Markets, Institutions and Money, Vol. 21 No. 5, pp. 637-661.

Trzcinka, C. (1986), "On the number of factors in the arbitrage pricing model", The Journal of Finance, Vol. 41 No. 2, pp. 347-368.

Tsai, I.-C. and Chen, M.-C. (2009), "The asymmetric volatility of house prices in the UK", Property Management, Vol. 27 No. 2, pp. 80-90.

Tse, Y. and Booth, G.G. (1996), "Common volatility and volatility spillovers between US and Eurodollar interest rates: evidence from the futures market", Journal of Economics and Business, Vol. 48 No. 3, pp. 299-312.

Vähämaa, S. and Äijö, J. (2011), “The Fed's policy decisions and implied volatility”, Journal of Futures Markets, Vol. 31 No. 10, pp. 995-1010.

Vrugt, E.B. (2009), "US and Japanese macroeconomic news and stock market volatility in Asia-Pacific", Pacific Basin Finance Journal, Vol. 17 No. 5, pp. 611-627.

Wang, Y., Ma, F., Wei, Y. and Wu, C. (2016), "Forecasting realized volatility in a changing world: a dynamic model averaging approach", Journal of Banking and Finance, Vol. 64 No. 1, pp. 136-149.

Wu, G. and Xiao, Z. (2002), "A generalized partially linear model of asymmetric volatility", Journal of Empirical Finance, Vol. 18 No. 5, pp. 287-391.

\section{Corresponding author}

Razali Haron can be contacted at: hrazali@iium.edu.my

For instructions on how to order reprints of this article, please visit our website:

www.emeraldgrouppublishing.com/licensing/reprints.htm

Or contact us for further details: permissions@emeraldinsight.com 